\author{
Pavel Krpalek, \\ Ph.D., Associate Professor, Finance and Accounting Department, \\ University College of Business in Prague, \\ Prague, Czech Republic \\ Katarina Krpalkova Krelova, \\ Ph.D., Economic Teaching Methodology Department, \\ University of Economics, \\ Prague, Czech Republic \\ Katerina Berkova, \\ Ph.D., Economic Teaching Methodology Department, \\ University of Economics, \\ Prague, Czech Republic
}

\title{
ENTREPRENEURSHIP IN RELATION TO CONTEMPORARY CONCEPTS OF EDUCATION
}

Creativity, initiative and entrepreneurship as the educational goals, and the key components of intellectual capital in the spirit of the European strategy "Education \& Training 2020" should be systematically developed at all levels of education. This is not about just narrowly focused preparation for future business, the aim is to guide learners to independence, activity, critical thinking, motivated approach to learning as well as responsible self-learning. In such a way graduates acquire all necessary preconditions for becoming a successful employee, manager and entrepreneur but they should be also prepared and motivated for lifelong learning. Such a complex competency profile to learners is only possible through using the contemporary education concepts based on activating methods as it is demonstrated in the article below. Our aim has been to present original research results concerning the level of actual use of the contemporary concepts of education in relation to the reality of teaching experience. The research questions and hypotheses posed below are directly related to the effectiveness of their application and match the combined research methodology, based on the exploratory methods, but are supplemented by observations and structured interviews as well. It can be stated that the professional development of teachers has not been sufficiently developed yet so that they could effectively develop students' entrepreneurial skills in terms of economic education in the Czech Republic. The presented results show that students of secondary economic schools are more and more exposed to traditional methods that cannot develop creative entrepreneurial skills. Students are not prepared enough in practical training, for surviving in the real economic world and conducting their own business activities. Based on the findings of the research are recommend some priorities and measures concerning the teaching of economic subjects.

Keywords: business economics, entrepreneurship, economic education, education concepts.

Introduction. Entrepreneurship education is a cross-sectional parameter, connected with the initiative and creativity, which aim is to shape learners' motivated approach to their professional career. Business graduates can always freely choose whether they enter the employment relationship, or start their own business, or continue their studies further. The school should create all necessary conditions for motivation and success, whatever option is chosen by graduates. As Marešová et al. (2014) state an enterprising man is such an individual who has the sense of initiative and entrepreneurship, perceived as the ability to see and effectively take advantage of the available opportunities. Recommendation of the European Parliament and the EU Council on the key competencies for lifelong learning in 2006 highlights the "sense of initiative and entrepreneurship". This refers to the ability to put ideas into practice assuming creativity, 
the ability to implement innovations, take risks, plan and manage projects in order to achieve the goals. These capabilities are beneficial for all individuals in their personal and professional lives. General knowledge plays an important role as well because it helps people with an understanding of the economy, finance and the possibilities or challenges that a typical employee, employer or corporation commonly face. People should also be more aware of the fact that companies have their ethical and social responsibility as well, they may serve as an example of good practice that is mediated image of the cultural level of the society (Chromý, 2006). The American Consortium for Entrepreneurship Education issued a document called "Entrepreneurship Strengthens Everyone", which highlights the importance of entrepreneurship, strengthening the economy overall. According to this consortium vision, skills associated with successful business should be taught, and it should be recognized that entrepreneurial skills are useful not only for business but also for personal life and employment in general. The importance of entrepreneurial spirit and entrepreneurship for society is the most evident precisely in the USA. Their small businesses are a strong part of the national economy for several reasons. They represent $99.7 \%$ of all employers nationwide and employ nearly half the people in the employment sector. In the last decade, this segment has been creating from 60 to $80 \%$ of new jobs. In particular, they hire $40 \%$ of high-tech workers such as scientists, engineers and IT specialists. Their personal characteristics may vary, but they have at least one thing in common - the repeated willingness to take risks for profit. Although the level of education is not a necessary requirement for starting a business, it helps to have supportive skills developed, such as communication, interpersonal skills, understanding of economics, information skills, knowledge of marketing, management and financial literacy. Risk-taking is the main source of new jobs, for both owners and employees. Activities in the context of entrepreneurship education are the real means to develop skills in these and many other subjects. Education enables employees to be more successful through an understanding of the activities of small businesses and the problems their managers are facing. Potential entrepreneurs can be found in all occupations and career groups. Having opportunities to implement entrepreneurship education is important at all levels of education (Marešová et al., 2014). The contents of entrepreneurship education should include the transfer of such knowledge, which will enable proactive identification and exploitation of market opportunities which will support professionally the abilities and the willingness of future entrepreneurs and managers to take acceptable risks, to continue to acquire knowledge - and to gain new skills through new activities - thus leading to more effective enterprises and entrepreneurship, the ability to prepare a successful business project or meaningfully manage own career (Malach, 2008b).

The authors of this article in relation to the abovementioned key aims present the latest unpublished results of their empirical research which are connected with the effective use of the contemporary concepts of education with the emphasis on activating methods (such as simulation method, case studies, business simulation games and problem-solving teaching methods), which develop creativity very well and prepare students for their own business activities and survival in the real economic world.

The results of this empirical research will be further used in the education process to develop entrepreneurship skills. In the analytical part of the paper, the formulated hypotheses are connected with the methodology of teaching efficacy through activating the teaching methods and their use by educators. It is therefore desirable to use properly the above-mentioned activating methods in the process of education. More specifically, if teachers are trained to apply contemporary methods of education, and if they are able to use such methods and tools efficiently, the development of entrepreneurial skills is nearly guaranteed. Therefore, our purpose here is to explore the education reality and to recommend the measures to improve the effectiveness of entrepreneurship education.

Literature Review. According to a recent survey carried out by Universum and agency Student Media for Czech students the second most important criterion in deciding their future professional career after work-life balance is creative and dynamic work environment, perceived as supporting new ideas, 
innovative working atmosphere, inspiring environment where they can realize their ambitions, learn from others, think independently, be creative. Respondents stressed the fact that they want to feel good at work and prefer the possibility to realize their inventiveness, even before the money ranking. The survey was conducted online from November 2015 to February 2016 and a sample of 14,500 respondents in the Czech Republic was addressed. The above-mentioned preferences illustrating priorities of learners in that survey can be seen in the following graph in figure 1

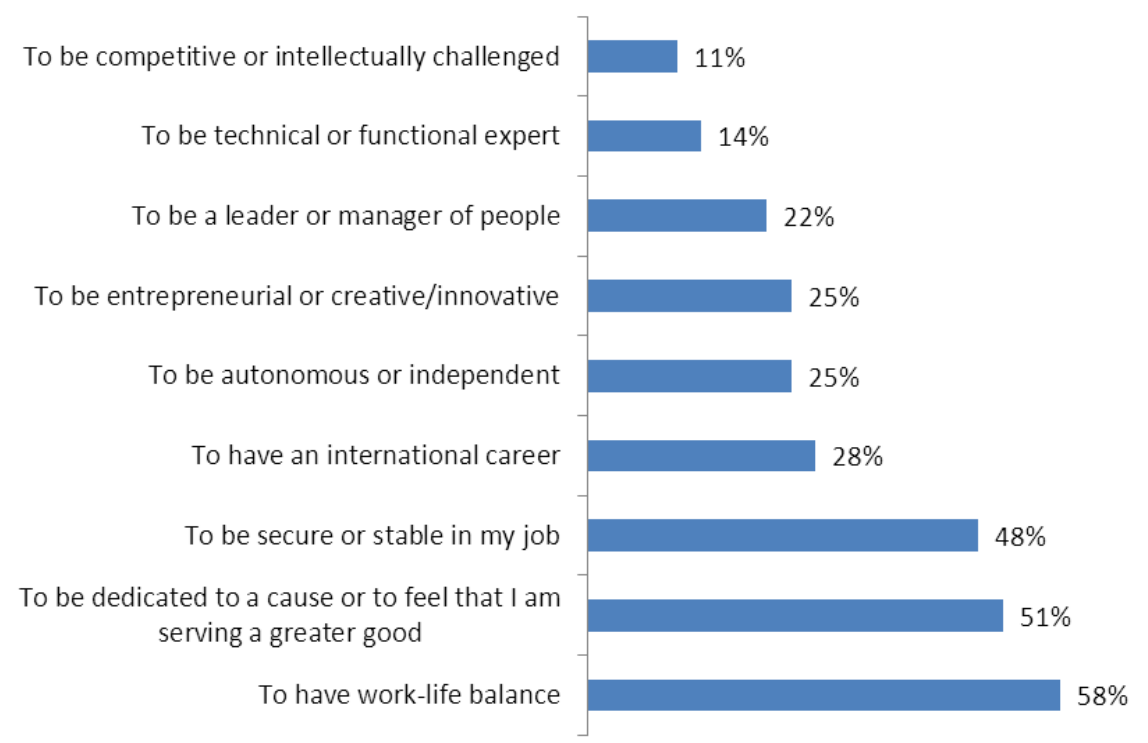

Figure 1 - Career goals - preferences in choosing professional career after finishing studies (Universum Talent Survey 2016, In: Keményová, Niedermeierová, 2016)

It is worth comparing the preferences of Czech students' survey results with students from Germany, Great Britain and the USA. The most noticeable difference is with the criterion "To be competitive or intellectually challenged", which is considered relevant by $11 \%$ of respondents from the Czech Republic compared to $35 \%$ of respondents from the USA, $37 \%$ of British respondents and $40 \%$ of German respondents. Other preferences are similar or they do not imply a significant difference. The relatively lower tendency to competitiveness in international comparison was identified as the most noticeable information.

In pursuing the objectives of the strategic framework for European cooperation in education and training "Education \& Training 2020" the support of developing entrepreneurship in education is growing in most European countries. Specific strategies to promote entrepreneurship education were already introduced in 2012 by eight countries (Denmark, Estonia, Lithuania, the Netherlands, Sweden, Norway, Wales and the Flemish part of Belgium) and thirteen others (Austria, Bulgaria, Czech Republic, Finland, Greece, Hungary, Iceland, Liechtenstein, Poland, Slovakia, Slovenia, Spain and Turkey) incorporated them into their lifelong learning strategies, strategies for youth or for growth. Entrepreneurship education has clearly defined its place in curricula from primary schools. Entrepreneurial thinking and acting is not taught at primary and secondary schools in separate subjects, but already at these levels of education there is a systematic effort to mediate the students the skills with entrepreneurship issues, such as a sense of active negotiations, the ability to take risks and creativity (Education, Audiovisual and Culture Executive 
Agency, 2012). An attempt to foster entrepreneurship through a range of educational approaches informal education which are in constant evolution is obvious. However, professional literature on entrepreneurship education often lacks empirical evidence for this effort. Fernandes et al. (2017) describe the educational approaches to promote entrepreneurship in the field of informatics. Within the course, he seeks to instil students with the knowledge of necessity to bring organizational aspects into line with commercial aspects in the decision-making of technical and business vision. Based on semi-structured interviews, relevant knowledge about the entrepreneurial process of teaching and learning styles preferred was obtained over a period of seven years. Priorities for support of entrepreneurial skills in developing and trading software including teamwork, development of projects and direct contact with the market were identified. Interesting business-oriented approaches are being developed in engineering education, where the traditional analytical logic has not always fully met the modern methods of doing business and previous models did not provide enough tools for organizing entrepreneurship education. Mäkimurto-Koivumaa and Belt (2016) have developed a new framework for entrepreneurship education and recommend to include it on every level of education and in tertiary education in each year of study while stressing the need to use appropriate activating methods that promote entrepreneurial skills and develop the personality of students. Explicit business and financial knowledge should be increased gradually during the study in accordance with the achieved level of economic education. Similar conclusions have been reached by the team of authors Mylonas, Kyrgidou, Petridou (2017) in research on the impact of creativity on the intentions of learners to do business after finishing studies (the relationship between creativity and entrepreneurship), following the publication of contemporary literature pointing to the importance of selected personality characters and adoption of the creation of a business plan. In that sense, empirical research was carried out which showed the influence of creativity in conjunction with the knowledge to prepare a good business plan. Interesting findings resulting from an extensive international research, which was carried out by Pruett and Sesen (2017) with the aim to analyse and compare the relationship between skills and perception of business including motivation, barriers, aspirations and their impact on entrepreneurial education. 3,037 teachers and educator in the United States, China, India, Turkey, Belgium and Spain participated in the research. The study includes students and educators of all disciplines to explore the perceptions of business motivations and barriers across different disciplines. The authors found out that in all six countries having very different culture, levels of economic and business environment, students evaluate themselves as more enterprising than how they are perceived by their teachers. Factor in the economic climate is considered the most important barrier to entrepreneurship by students and the lack of experience and inability to communicate effectively is perceived as a handicap. The authors have proven that self-confidence, risk attitudes and students' disposition to do business require increased attention in the process of curriculum preparation. Entrialgo and Iglesias (2016) analysed to what extent the interaction between business education and subjective norms have been influencing perceptions and attitudes towards entrepreneurship. They demonstrate that entrepreneurship education has a moderating role in the relationship between subjective norms, and perceived behavioural control and that it strengthens the relationship between subjective norms and business attitudes. Westhead \& Solesvik (2016), Belas et al. (2015) and Kozubíková et al. (2017) did a comparison of relation to entrepreneurship and risk-taking willingness among students of economic branches with entrepreneurship education and students of non-economic fields who did not participate in entrepreneurship education. The performed regression analysis revealed that students of economic subjects who participated in entrepreneurship education have a greater inclination to carry out the business, thus more inclined to do business. The authors recommend the teaching switch from transmissions to the case studies and the acquisition of skills, recommending the strengthening of discussion of theoretical and practical issues of entrepreneurship, experimental learning and discussion with successful entrepreneurs. Belas et al. (2016) proposed to create more room for increased use of modern teaching methods in order to improve 
application skills of students. In this context, it is necessary to focus on the use of modern methods that promote creativity and initiative of students (case studies, problem- solving method and brainstorming). The current method of teaching traditionally focuses on gaining encyclopaedic knowledge that can be more useful in the knowledge competition, than the real life. In connection with the modern concepts of education case study simulation methods, business simulation games and problem-solving teaching methods are important for entrepreneurship education. Those methods have in common the fact that students can try a particular decision-making activities, learn to identify the problems and propose their solution in various versions with the ability to defend their proposal supported with factual arguments. The methods also lead to the ability to take the whole apart, analyse and evaluate the situation. Case study method is characterized by illustrating either the real or virtual situation, from which students must be able to identify the core of the problem, bring it into the decision-making process of the company, and break down the situation in terms of risks, opportunities of firms with the appropriate level of responsibility. Case studies allow to simulate the real environment and to develop students' creative thinking efficiently in the context of entrepreneurship education compared to business simulation games which have clear rules and a different form and they can be modified into the following types - non-interactive games that are simple and fun, should increase students' motivation to study; Interactive games are based on the interaction of all participants, they usually are of a more complex and sophisticated character. They simulate real conditions of economic situations. They are highly significant for the development of entrepreneurial skills. They are based on the fact that according to their decision the participants react to the moves of opponents to adapt to the current situation of the game. As it happens in real life - time and the sense of making immediate decisions play a very important role in the economic environment in relation to the evaluation of their capital. Simulation methods (case studies, economic and educational games) are based on problem-solving teaching, which belongs to the modern concepts of education (Berková et al., 2016). In the Czech Republic, however, traditional methods are still dominating developing students' understanding of the issues, but not developing the necessary skills for entrepreneurship education, i.e. analysing, evaluating and creativity (creative economic thinking). These methods are frequently used abroad. Simulating of the real environment in terms of international education process belongs these days among common teaching methods for the development of business skills (Zoller, 2015; Tetteh, Sarpong, 2015; Subroto, 2015).

Schelfhout et al. (2016) focused on the neglected sphere of evaluation of entrepreneurship education. The authors developed an evaluation tool to be used for self-assessment, peer review, and from the very beginning of the learning process, using techniques of coaching, feedback and they emphasized the need for discussions with students. The teacher must set clear conditions and must have a reasonable expectation, must support and guide the learning process in a motivating way with continuous feedback.

Conceptual Approach to Research, Objective and Hypotheses. The basic prerequisite for the effective development of entrepreneurship education through modern concepts of economic education is the proper and effective use of participants in the teaching process. The main thesis of the research comes out of the idea whether teachers use activating methods, which represent a modern approach to business education, in a way ensuring the effectiveness of teaching, or if teachers are educated in this area sufficiently and capable of using activating methods effectively and efficiently. The aim of the research is to determine the effectiveness and efficiency of use of activating methods by educators in the process of learning in economic education which can be used for developing the education for entrepreneurship of students in terms of secondary education. The authors explore the use of simulation method of case study, business simulation games and problem-solving teaching method in the education process that provide practical training of students for real economic situations. Given the need to ensure the appropriate effect of teaching-oriented education to entrepreneurship it is essential for teachers to be educated adequately in modern concepts of economic education (researched activating methods) and to be able to use these 
methods properly and effectively in a way that ensures that their effort will have the required effect. Therefore, the research focuses on the professional development of teachers as well and their interest in further education in the field of modern education concepts. The main hypothesis comes out of the aim of the research and it is divided into three closely related sub-hypotheses:

The main hypothesis $(\mathrm{H})$ : The way of using activating methods by teachers in economic education guarantees effective leading of a teaching unit.

- The sub-hypothesis (H1): There is a correlation between the interest of teachers in professional development in the field of activating methods and their feeling to be educated sufficiently in this area.

- The sub-hypothesis (H2): Greater usability of activating methods by teachers depend on the length of their teaching experience.

- The sub-hypothesis $(\mathrm{H} 3)$ : Teachers use activating methods in teaching correctly, which lead to the development of students' entrepreneurial skills.

The main hypothesis will be verified if all three hypotheses are proven.

Methodological Approach. Respondents, Research Sample. There were 37 secondary schools specializing in economic education in the research carried out in 2015 out of 60 addressed respondents in the Czech Republic. Secondary schools from 13 regions took part in the research.

This particular research sample was created by the deliberate choice of secondary school, which was conditioned by the necessity of providing of economic programmes of secondary schools with a focus on the field of education for secondary business schools (Obchodní Akademie). The correctness and adequacy of activating methods for this field of study in relation to the education process acquiring entrepreneurial skills were researched. The content of education and the graduate's profile in this field is integrated except for the nuances. This type of school prepares students primarily for economic practice and conducting their own business activities. This single graduate's profile should guarantee a certain consensus in the procedures and methods that promote active learning through modern concepts of education. Therefore, it can be assumed that teachers should benefit from good teaching strategies and methods for simulating real-life situations and know exactly how to use them in the classroom. At the level of individual respondents - teachers - the return of questionnaires was 38 completed questionnaires out of 37 secondary schools (including 36 women and 2 men). Respondents differ in the length of teaching experience, which was observed at the following intervals: more than 20 years $(55.3 \%), 16-20$ years $(5.3 \%), 11-15$ years $(18.4 \%), 5-10$ years $(15.8 \%), 2-4$ years $(2.6 \%)$, less than two years $(2.6 \%)$. This character was subsequently used to demonstrate the relationship between the length of teaching experience and usability of activating methods.

Materials and Methods. The authors' research applied quantitatively oriented strategies based on the quantitative statistical analysis. The research tool for data collection was the authors' web design questionnaire which was distributed electronically. Before the research started there was conducted a pilot study in which seven teachers from business schools focusing on teaching economic subjects participated and they matched the characteristics of respondents from the main research. The aim of the pilot study was primarily to ensure content validity and reliability of the research tools. The questionnaire included open and closed questions using the interval and Likert scale. The respondents' answers followed three areas that related to the professional development of teachers in the field of modern education, the use of activating methods in education and their efficient and effective use (in terms of correct interpretation of selected methods). The first area was aimed to determine the relation between the interest of teachers for professional development in the field of modern education (with an emphasis on supporting active learning approach) and their feeling to be educated enough in this area. This part of the questionnaire will bring clearly demonstrable results on the subjective perception of teachers concerning their skills to use activating methods effectively. The second part of the questionnaire was aimed at demonstrating the relationship between the length of teaching experience and the use of activating methods in terms of their 
range. This section will demonstrate whether the use of activating methods by teachers in economic education is random or their use in the education is given by the length of teaching experience of participants of learning process. The third and final part of the questionnaire examined the accuracy of the interpretation of activating methods by teachers. Teachers interpreted simulation methods (case study), methods of economic games with elements of examples of problems in terms of content and the form of assignment. This section will show whether teachers name methods by the correct terms and consider them as activating methods. To get an objective evaluation of this comparison information from the first part of the questionnaire was used focusing on the professional development of teachers in the field of modern education.

To verify the hypothesis 1 and 2 , the data was processed and analysed by using the statistical program NCSS (version 2007) based on statistical methods Chi-square test of independence, at $5 \%$ significance (P-level 0.05). This test allows showing dependence (or independence) between two variables. It can be used in determining the relationship between two qualitative or ordinal variables which have several categories (the categorical or alternatively categorical variables). Based on this test, the significance (PLevel) was calculated and it was compared with the significance level of $5 \%(p=0.05)$. According to Weiss (2012), it is necessary to reflect several assumptions in the construction of the chi-square test of independence. The null hypothesis $\mathrm{HO}$ declares that the observed features are independent, alternative hypothesis $\mathrm{H} 1$ is then hypothesis about their dependence. To determine whether empirical frequencies $n_{i j}$ are or are not inconsistent with the hypothesis $\mathrm{HO}$ about the independence of the two characters, it is necessary to construct a so-called theoretical (expected) frequencies $e_{i j .}$. The probabilities of permutations of each character are estimated by relative frequencies in the form of:

$$
\frac{n_{\cdot i} n_{j}}{n^{2}},
$$

where: $n_{. i} n_{j}$ = marginal frequency (frequency totals in rows and columns), $n=$ selection of range divided by two statistical characters.

Theoretical (expected) rate $e_{i j .}$ take this form:

$$
e_{i j}=\frac{\mathrm{n}_{\cdot \mathrm{i}} \mathrm{n}_{\mathrm{j}}}{\mathrm{n}}
$$

Test criterion $\mathrm{G}$ is then based on the differences $n_{i j}-e_{i j .:}$

$$
G=\sum_{i=1}^{r} \sum_{j=1}^{c} \frac{\left(\mathrm{n}_{\mathrm{ij}}-\mathrm{e}_{\mathrm{ij}}\right)^{2}}{\mathrm{e}_{\mathrm{ij}}}
$$

where: $r=$ number of rows of a contingency table, $c=$ number of columns of the contingency table.

The third hypothesis was evaluated based on a qualitative analysis of the teachers' responses to open questions based on the highest consensus (or contradictions) of their answers with the expected result.

Results. Based on a chi-square test of independence of two qualitative variables, two sub-hypotheses $\mathrm{H} 1$ and $\mathrm{H} 2$ were verified. Data were analysed by the statistical program NCSS (2007 version). The report of results is adapted to the form generated by the program.

Verification of Sub-hypotheses (H1; H2) based on Chi-square Test. To verify the sub-hypotheses, the null hypothesis $\mathrm{HO}$ was always formulated and relating to it as well as the alternative hypothesis $\mathrm{H} 1$. 
For the purposes of statistical verification, these hypotheses are listed below.

Hypothesis 1. Ho-1: There is no dependence between the interest of teachers in professional development in the field of activating methods and their feeling to be educated enough in this area.

$\mathrm{H}_{1-1}$ : There is a dependence between the interest of teachers in professional development in the field of activating methods and their feeling to be educated enough in this area.

Hypothesis 2. $H_{0-2}$ : Higher usability of activating methods by teachers does not depend on the length of their teaching experience.

$\mathrm{H}_{1-2}$ : Higher usability of activating methods by teachers depends on the length of their teaching experience. Tables 1 and 2 provide the results of the marginal frequency of the analysed statistical features.

Table 1 - Cross Tabulation Report - Hypothesis 1(Own Research)

\begin{tabular}{|c|c|c|c|c|}
\hline & \multicolumn{4}{|c|}{ Profession Development } \\
\hline Abilities of Teacher & 2 & 3 & 4 & Total \\
\hline 1 & 0 & 0 & 1 & 1 \\
\hline 2 & 2 & 6 & 4 & 12 \\
\hline 3 & 6 & 8 & 8 & 22 \\
\hline 4 & 0 & 1 & 2 & 3 \\
\hline Total & $\mathbf{8}$ & $\mathbf{1 5}$ & $\mathbf{1 5}$ & $\mathbf{3 8}$ \\
\hline
\end{tabular}

Table 2 - Cross Tabulation Report - Hypothesis 2 (Own Research)

\begin{tabular}{|c|c|c|c|c|c|c|c|}
\hline & \multicolumn{7}{|c|}{ Practice } \\
\hline $\begin{array}{c}\text { Utility of } \\
\text { Activating } \\
\text { Methods }\end{array}$ & 1 & 2 & 3 & 4 & 5 & 6 & Total \\
\hline 1 & 0 & 0 & 0 & 1 & 0 & 0 & 1 \\
\hline 2 & 0 & 0 & 1 & 4 & 1 & 3 & 9 \\
\hline 3 & 2 & 0 & 1 & 1 & 0 & 5 & 9 \\
\hline 4 & 0 & 1 & 2 & 1 & 1 & 10 & 15 \\
\hline 5 & 0 & 0 & 1 & 0 & 0 & 3 & 4 \\
\hline Total & $\mathbf{2}$ & $\mathbf{1}$ & $\mathbf{5}$ & $\mathbf{7}$ & $\mathbf{2}$ & $\mathbf{2 1}$ & $\mathbf{3 8}$ \\
\hline
\end{tabular}

The results of the verification of both null hypotheses $\mathrm{H} 0-1$ and $\mathrm{H} 0-2$ are based on the quantitative statistical method of the chi-square test of independence and are presented in Table 3.

Table 3 - Chi-Square Test (Own Research)

\begin{tabular}{|l|c|c|c|c|}
\hline & $\begin{array}{c}\text { Chi-Square } \\
\text { Value }\end{array}$ & Degrees of Freedom & $\begin{array}{c}\text { P-Level } \\
(\mathrm{p})\end{array}$ & Accept/Reject \\
\hline $\mathrm{H}_{0-1}$ & 3.828788 & 6 & 0.699833 & Accept $\mathrm{H}_{0-1}(\mathrm{P}>0.05)$ \\
\hline $\mathrm{H}_{0-2}$ & 17.624921 & 20 & 0.612101 & Accept $\mathrm{H}_{0-2}(\mathrm{P}>0.05)$ \\
\hline
\end{tabular}

The authors do not reject both null hypotheses at $5 \%$ significance $(p=0.699833 p=0.612101)$. The research clearly shows the independence of the statistical characteristics. Regarding to the fact that $65.8 \%$ of respondents feel sufficiently educated in the field of modern education and a statistical relationship to further develop their professional education in this area has not been proven, it would be possible to 
conclude according to this result that teachers feel able to use mainly simulation method of case study, business simulation methods and problem-solving teaching method efficiently and effectively and activate students in an effective way. From another perspective, it can be stated that teachers do not pay enough attention to their professional development in the field of modern educational concepts, even though they think to be educated enough in this area, which can be considered as a negative factor preventing the efficient management of teaching units leading to the development of entrepreneurship education for students. At the same time, the results show clearly that using of activating methods in terms of their range by teachers is a mere randomness regardless of the length of their teaching experience.

Qualitative Analysis of the Sub-hypothesis $\mathrm{H}_{3}$. To find out if teachers consider themselves justifiably educated in the use of activating methods in the education process, the authors asked teachers in a questionnaire on defining of selected activating methods which are most often used within the concept of the problem-solving method of teaching within economic subjects. The results of this quality research are summarized in the text.

In terms of the accuracy of interpretation of simulation method case studies, economic games and examples with elements of problems, gaps in knowledge of teachers were noted regardless of the length of teaching experience. $50 \%$ of teachers equated examples with elements of problems with the traditional example, which does not contain problem-solving issues or tasks (i.e. the difficulties that a student must overcome by using other than the learned algorithm). A case study, on the contrary, was equated with a continuous example $(60.5 \%)$, which the main feature is a solution of the task, other $18.4 \%$ of respondents did not answer at all. Teachers most often considered staging methods or elementary teaching aids crosswords $(52.6 \%)$ to be economic games. $13.2 \%$ of respondents did not answer.

By such a comparison the authors found out that teachers misinterpreted activating methods. Answers show that teachers use stereotyped teaching methods, for which they only use the names of modern teaching methods, even though they think to be sufficiently educated in modern concepts of education. Methods that teachers really use teaching students develop lower-level skills, not preparing them for fullyfledged economic life. These methods of teaching are primarily oriented to encyclopaedic knowledge, memorizing subject matter not related to the development of decision-making, analytical skills.

All sub-hypotheses were not confirmed. As a result, the main hypothesis was not confirmed either: The way of using activating methods by teachers in economic education guarantees effective leading of a teaching unit. It can be stated that the professional development of teachers has not been sufficiently developed yet so that they could effectively develop students' entrepreneurial skills in terms of economic education in the Czech Republic. The presented results show that students of secondary economic schools are more and more exposed to traditional methods that cannot develop creative entrepreneurial skills. Students are not prepared enough in practical training, for surviving in the real economic world and conducting their own business activities.

Discussion and Conclusions. Carried out survey brought surprising finding in the form of rejection of the hypothesis concerning the fact that current approaches to use of activating teaching methods in teaching process guarantee efficient management of education in relation to education in entrepreneurship. It concerns secondary vocational education in which compared to tertiary education teachers under the Act on Educational Staff must meet the condition of required qualification, specifically speaking qualification for the teaching of specialized subjects. It is beyond doubt that using qualified to activate teaching methods by motivated and capable teachers would under normal circumstances lead to a provably more effective teaching, among others in relation to entrepreneurship education. It is demonstrated by the research carried out at the authors' workplace, published in resolving internal grant University of Economics, Prague IGA F1/31/2015 "Implementation of Case Studies and Economic Games to Secondary Education in the Context of the Development of Economic Thinking and Improving the Penetrability of Tertiary Education "disseminated within the international scientific conference "Schola 
nova, quo vadis" (7.11.2016, University of Economics, Prague), specialized publication "Case Studies and Teaching Economic Games or How to Motivate Students to Business Subjects. Examples and Solutions" (Berková et al., 2016) and supported by the methodical online portal http:/lucitelstvi.vse.cz. The proliferation of results and their transfer into the real teaching process does not correspond to the expectations and needs. Based on the findings the research department, which has a 55-year tradition in preparing teachers of economic subjects, is innovating curriculum and preparing educational events both in undergraduate teachers education and in lifelong education courses implemented as a complementary educational sciences studies concerning the teaching of economic subjects and in further education of teachers. From the teaching methodology point of view, we recommend the following priorities and measures:

- to handle the paradigm shift from transmission to social constructivism, prefer concentric organization of the curriculum and the inclusion of integrated forms of education, particularly training companies and student companies,

- to strengthen the character of the activity of teaching and facilitation style versus executive style, usually associated with a tendency to narrow the teaching methodology towards teaching methods using monologues, with a tendency to encyclopaedism and forced memorization,

- significantly strengthen using of activating teaching methods to train teachers in this sense in lifelong learning programmes as well as in undergraduate teacher training programmes,

- in the education to focus on individual approach, to promote natural learning styles of students to develop their independence, teamwork and creativity, i.e. strengthening the independent activities of autonomous learners in education; a prerequisite for educators is the acceptance and mastery of facilitation teaching method,

- to strengthen students' skills find and analyse information and a wide range of target key competencies, to adopt the educational concept in the way so that there is a natural support for the development of students' abilities to effectively search, analyse and use information and opportunities, be able to evaluate them realistically, take and bear the associated risks,

- to develop students' ability to improvise, to have a creative and innovative approach to solving everyday tasks using project management knowledge,

- to reflect the principle of self-responsible learning in practice, i.e. the ability and willingness of learners to take responsibility for their own learning, for their results, in the longer term, even for their own life, success and career.

Acknowledgement. The research leading to these results was supported in the frame of the Grant Agency of Academic Alliance, project number 7/2018 and Internal Grant Agency of the University of Economics, Prague under the Grant agreement number IGS F1/31/2015 and it is part of a project of Faculty of Finance and Accounting carried out with help of institutional support the University of Economics under the Grant agreement number IP100040

Belás, J., Nguyen, A., Smrčka, L., Kolembus, J., Cipovová, E. (2016), Financial Literacy of Secondary School Students. Case Study from the Czech Republic and Slovakia, Economics and Sociology, Vol. 9, No 4, pp. 191 - 206. DOl: 10.14254/2071 789X.2016/9-4/12, referred to on 07/01/2017

Belás, J., Ključnikov, A., Vojtovič, S., Sobeková-Májková, M. (2015), Approach of the SME Entrepreneurs to Financial Risk Management in Relation to Gender and Level of Education, Economics and Sociology, Vol. 8, No 4, pp. 32-42. DOI:10.14254/2071789X.2015/8-4/2

Berková, K. et al. (2016), Prípadové studied a didaktické ekonomické try aneb jak motivovat studenty k ekonomickým predmětům. Príklady a řešení. Praha: Oeconomica, 137 p., ISBN 978-80-245-2164-0.

Berková, K. (2016), Úloha informačních technologii v cvičné firmě. In: CHROMÝ, Jan (ed.). Media a vzdělávání 2016 [online]. Praha: Extrasystem Praha, pp. 14 -17. ISBN 978-80-87570-35-7. Available online at: http://extrasystem.com/9788087570357.pdf, referred on 05/01/2017

Education, Audiovisual and Culture Executive Agency. (2012), Entrepreneurship Education at School in Europe. National 
Strategies, Curricula and Learning Outcomes. ISBN 978-92-9201-252-6. [on-line]. Available online at: http://eacea.ec.europa.eu/education/eurydice, referred on 04/01/2017

Entrialgo, M., Iglesias, V. (2016), The moderating role of entrepreneurship education on the antecedents of entrepreneurial intention. International Entrepreneurship and Management Journal. Vol. 12, Issue 4, pp. 1209 - 1232. Available online at: http://link.springer.com.ezproxy.lib.cas.cz/article/10.1007\%2Fs11365-016-0389-4, DOI: 10.1007/s11365-016-0389-4, referred on 03/01/2017

European Commission. (2013), Entrepreneurship education: A guide for educators. Brussels: Entrepreneurship and Social Economy Unit.

Fernandes, J. M., Afonso, P., Fonte, V., Alves, V., Ribeiro, A. N. (2017), Promoting entrepreneurship among informatics engineering students: insights from a case study. European Journal of Engineering Education. Vol. 42, Issue 1, 2017 , pp. 91 - 108. Available online at: $\mathrm{http}: / / \mathrm{dx}$.doi.org/10.1080/03043797.2016.1197891, referred on 04/01/2017

Chromý, J. (2016), Motivating Aspects and their Barriers to Studying Vocational Schools: The Example from the Field of Gastronomy, Media4u Magazine, Prague, Issue 2, Vol. XIII., pp. 12-16, ISSN 1214-9187, available online at http://media4u.cz/mm022016.pdf, referred on 06/17/2016.

Keményová, Z., Niedermayerová, J. (2016), Téma: Průzkum společnosti Universum o preferencích českých vysokoškolských studentů, podle čeho vybíraji firmu, do které nastoupí. Magazine ProByznys, Economia. Příloha Hospodářských novin, 24. 11. 2016. pp. $4-8$.

Krpálek, P., Krpálková Krelová, K. (2012), Didactics of Economic Subjects, 1st. Ed., Prague: Oeconomica, ISBN 978-80-2451909-8.

Kozubíková, L., Dvorský, J., Cepel, M. \& Balcerzak, A. P. (2017). Important characteristics of an entrepreneur in relation to risk taking: Czech Republic case study. Journal of International Studies, 10(3), 220-233. doi:10.14254/2071-8330.2017/10-3/16

Malach, J. (2008a), Výchova k podnikavosti. Vysokoškolská učebnice, vyd. 2., Ostrava: Ostravská univerzita, 2008, 88 s., ISBN 978-80-7368-552-2

Malach, J. (2008b), Výchova k podnikavosti a vysoké školy. Aula, Vol. 16, Issue 02/2008, [online] available at: http://www.csvs.cz/aula/clanky/2008-2-vychova-k-podnikavosti.pdf, referred on 11/12/2012

Marešová, H., Rudolf, J., Hladík, T. (2014), Výchova k podnikavosti. Výstup projektu ESF, OP Vzdělávání pro konkurenceschopnost: Rozvoj podnikatelských dovedností žáků (ROPODOV), CZ.1.07/1.1.25/03.011. s. 6 - 7. Olomouc: Univerzita Palackého. ISBN 978-80-244-4436-9.

Mäkimurto-Koivumaa, S., BELT, P. (2016). About, for, in or through entrepreneurship in engineering education. European Journal of Engineering Education. Vol. 41, Issue 5, pp. 512 - 529. Available at: http://dx.doi.org/10.1080/03043797.2015.1095163, referred on $07 / 01 / 2017$

Mylonas, N., Kyrgidou, L., Petridou, E. (2017), Examining the impact of creativity on entrepreneurship intentions: the case of potential female entrepreneurs. World review of entrepreneurship, management and sustainable development [1746-0573]. Vol. 13, Issue 1, pp. 84 - 105. Available online at: http://www.inderscience.com/offer.php?id=80749, referred on 05/12/2017, DOI: 10.1504/WREMSD.2017.080749, referred on 03/01/2017

Pruett, M., Şeşen, H. (2017), Faculty-student perceptions about entrepreneurship in six countries. Education and Training. Vol. 59, Issue 1, pp. 105 - 120. Available online at: http://www.emeraldinsight.com.ezproxy.lib.cas.cz/doi/pdfplus/10.1108/ET-03-20130028, DOI: http://dx.doi.org/10.1108/ET-03-2013-0028, referred on 07/01/2017

Schelfhout, W., Bruggeman, K., DE Maeyer, S. (2016), Evaluation of entrepreneurial competence through scaled behavioura indicators: Validation of an instrument. Studies in Educational Evaluation. Vol. 51, pp. 29 - 41. Available online at: http://dx.doi.org.ezproxy.lib.cas.cz/10.1016/j.stueduc.2016.09.001, referred on 21/12/2016

Weiss, N. A. (2012), Elementary statistics. Boston: Addison-Wesley, 588 p. ISBN 978-0-321-70998-1.

Subroto, W.T. (2015), Creative Thinking Development to Foster Economic Creative: Evidence of State University of Surabaya. International Review of Management and Marketing. Vol. 5, No 3, pp. 108-113.

Tetteh, G.A., SARPONG, F.A. (2015), Infuence of Type of Assessment and Stress on the Learning Outcome. Journal of International Education in Business. Vol. 8, № 2, pp. 125-144.

Westhead, P., SOLESVIK, M. (2016), Entrepreneurship education and entrepreneurial intention: Do female students benefit? International Small Business Journal. Vol. 34, Issue 8, pp 979 -1003. Available online at: http://journals.sagepub.com.ezproxy.lib.cas.cz/doi/pdf/10.1177/0266242615612534,

Zoller, U. (2015), Research-Based Transformative Science/STEM/STES/STESEP Education for. „Sustainability Thinking“ : From Teaching to „Know" to Learning to „Think“. Sustainability. Vol. 7, No 4, pp. 4474-4491.

П. Крпалек, Ph.D., доцент, Університет бізнесу в Празі (Прага, Чеська Республіка);

K. Крпалькова Крелова, Ph.D., Економічний університет (Прага, Чеська Республіка);

K. Беркова, Ph.D., Економічний університет (Прага, Чеська Республіка).

Підприємницькі компетенції у сучасній освітній концепції

Однією із головних иілей прийнятої європейської стратегії «Освіта та навчання 2020» $\epsilon$ розвиток інтелектуального капіталу, креативності, ініціативності та підприємницького духу осіб, що навчаються. У зв'язкуз цим

http://mmi.fem.sumdu.edu.ua/en 
необхідною є адаптація традиційної системи освіти до сучасних вимог шляхом впровадження нових освітніх компонент у навчальні програми на всіх рівнях. Автори наголошують, що необхідним є застосування комплексного підходу до розвитку компетенцій осіб, що навчаються. Тобто основною метою є розвиток не стільки підприємницьких компетенцій учнів, а скільки розвиток їх креативності, незалежності, здатності до критичного мислення, саморозвитку та самонавчання. Використання даного підходу дає можливість набути учнями необхідних професійних навичок, що забезпечать їх конкурентоздатність на ринку праиі. У статті автори наголошують, що набуття учнями ефективного профілю компетенцій можливе лише за рахунок сучасної освітньої концепції, яка базується на активних методах навчання. Метою статті $є$ аналіз існуючої системи освіти та оцінка ефрективності використання активних методів навчання у сучасних умовах. У ході дослідження використовувались наукові методи діагностики, статистичного аналізу, спостереження та структуровані інтерв'ю 60 респондентів Чехії у 2015 році (37 загальноосвітніх шкіл з 13 регіонів, які спеціалізуються на економічній освіті). Результати дослідження свідчать, що професійні навички викладацького складу (зокрема - використання активних методів навчання) не відповідають потребам сучасної молоді щодо розвитку ї підприємницьких компетенцій. При иьому отримані дані свідчать про перевагу у використанні традиційних методів навчання, що обмежують творчий потенціал учнів та його розвиток. Як наслідок, молодь не отримує практичних навичок та знань, що тим самим унеможливлює ії розвиток у сучасних економічних умовах. У роботі автори систематизували рекомендації та першочергові заходи щодо переорієнтації існуючої системи викладання на приклад навчальних програм економічного спрямування.

Ключові слова: економіка, бізнес, підприємництво, економічна освіта, концепція освіти. 